\title{
しつけ調查における記名と無記名の問題*
}

\author{
一一質問紙法に関する一研究—
}

$\begin{array}{lllll}\text { 名古屋大学教育学部 } & \text { 石 } & \text { 黒 } & \text { 大 } & \text { 義** } \\ \text { 野間教育研究所 } & \text { 藤 } & \text { 原 } & \text { 喜 } & \text { 悦 }\end{array}$

\section{I 問题の概镜}

しつけの型や親の子どむに対する態度を把えるために は，钼察法・面接法・質間紙法・プロジェクト法などか ある。われわれはまず，啠䦥紙法によつてしつけの型を 把握する意四の下に，後述の如き調查問題を作製した。 そのさい, 記名要因が調查秸果を歪めはしないか, 記名 と無記名とでは両親の回答結果傹な差異が生ずるの ではないかという問題か，第一にとり上げられた。

元来, 留間紙調查法は心理学的研究の主要な一力法と して採用されてきたにるかかわらず，記名要因の影算に 関する方法論的検討は，次に述べように多くはなされ ておらず，ての問題に関する組樴的な研究はほとんどな されていないといってよい。

L.v.Koos (1) の研究によると，一般值人について の事実户意見・態度などには，記名は不利の方向に導く といら結果が示されている。

また，J.B.Mallen (2) の研究ては，記名事態法無記 名部態よりも。クラスのための仕事においては協力性を 增加させ，更汇級友の品等に打いては壸しく好意的な品 等を与えており，児童に関するかぎり無記名の方が自然 な応答を得るのに有利であると結論されている。

W.C. Olson (3) は, 教育心理課程の女子大学生につ wと, Woodworth-Mathews Personality Data Sheet を2回連繶して行い，第一群には第 1 回目調査を記名 で，第 2 回目調查を無記名で記入させ，第二群には無記 名一記名の順序で記入させた。その結果によると，第 1 回目調査汇関しては無記名群の方が記名群よりも。一般 的非現実感・退屈感・逃避の要求・神程症的身体徽倨な

* Signed Versus Unsigned Questionnaires of me Pattern of Parental Attitude toward Children

-A study of Questionnaire Method-

** by Ishiguro, Taigi (Nagoya University) and Fujiwara, Kietsu (Noma Institute of Education)
どを報告しやすかつたが，好み・特殊な恐怖・衝動など については, 両群の間に大きな差異は見られなかつた。 なお第回 1 目調查之第 2 回目調查との間に生ずる变動に 夙しては、雨群の間に有意味な差異が見られなかつた。 ての点汇関して，彼は，第 1 回目調查で両群ともその調 查に対してそれ艺れの構えができたためか, あるいは記 憶の要因が作用したためではないかと説明している。

また，R.P.Fischer (4) は，心理学専攻の女子大学生 に, Mooney の Problem Check List を一週間の間隔 で 2 回実施した。第 1 回目には記名，次に無記名で回答さ せたのであるが,その結果によると, 個人に重要な関保を 持たない調查問邀に対する応答は，両条件の下でほとえ ど差異がなかつたが，重要な成係を持つ調查問題に奶す る応答は，無記名条件による方がはるかに多くなされた。

わが国においては，松井・羽場の共同研究 (5) が行わ れた。これは人事院の採用試験に上野式向性検查を「て れは試験ではないから」という注意を与えた後に，第 1 群には無記名 $\rightarrow$ 記名, 第 2 群には記名 $\rightarrow$ 無記名の順序で 2 回連繶して行つたものである。被調查者は新制高校卒 業程度の人々であるが、結果は記名・無記名の二条件下 における変動は，両群間にほとんど差異のないことが明 らかにされている。

以上の諸研究を検討してみると，質問紙調查法におけ る記名要因の問題は，次の四つに要約するととが可能で あろう。

（1）質問紙で調查しょうとする問題の内容が，被調 查者にとつて如何なる意味を持つるのであるかというこ とが最も重要となる。調查問題が回答者について，何等 かの価值評価をなすものであるか否かは，調查結果に記 名要因が大きく作用するととになるであろう。したがつ て, 調查問題の表現がきわめて重要な役割を持つものと 考えられる。

（2）質問紙調查が如何なる社会的事態においてなさ れるかが，記名要因の作用に重大な影響を及ぼす。調查 実施にあたつて，調查の趣旨を説明することも条件統整 
の一手段であるが，それ以上にその調查が如何なる社会 的現実の中でなされるものであるかが問題となる。例え ば「この調查は試験とは無関係なものである」と如何に 注意したとしても，就職試験などで調查を行えば，被調 查者に何らかの構えを作らせてしまうことはほぼ確実で あり、このために記名と無記名とが必ずしも調查者の意 図した条件統整法にはならないことになる。

（3）次に被調查者の精神的発達段階が重要な条件と なる。同じような調査を異なる精神発達段階にある集団 に実施した場合には，記名要因は必ずしも同じ作用をす るとは限らない。

（4）また，被調查者が如何なる社会的・文化的環境 の中で生活して来ているかということが，重要な問題で ある。今後の実証的研究に俟たなければ確言はできない が，例えは，鎖ざされた社会に生活する者之開かれた社 会に生活する者とでは，記名要因の作用の仕方に差異が あるものと考えられる。

\section{II 研究の目的}

ここに報告するわれわれの研究は，質問紙調查法にお ける記名要因の作用に関して組織的包括的な検討を行つ たものではない。われわれの作製した質問紙が，記名式 と無記名式のどちらを採用することによつて, より良く しつけの現実を把握できるかを検討するために，まずて の両方式の閒に有意な差異が生ずるか否かを明らかにす る必要にせまられた。もしこの両方式の間に有意な美異 が生じたならば，次にいずれがよい方法であるかの研究 を進める必要があり，また両方式の間に有意な差異がな いならば，個々の調查結果を利用する上に便利な記名式 を採用することが可能となる。

われわれは，質問紙によつて親の子どるに対するしつ け態度を調查する場合に，記名要因の働く方向として次 の三つを予想している。

（1）親は担任教師に对して自分の子どるおよび自己 をよりよく評価してるらいたいと考え，日常自分が実際 に行つているしつけ態度よりる，親自身が望ましいと考 えているしつけ態度を報告するかる知れない。

（2）担任の教師に対して，親が意識的無意識的に劣 等感ないしは無力感を抱いているときには，親は過度に きびしい自己反省を行つて, 家庭の実際場面で多くとつ ているしつけ態度をあからさまに表現することをためら い,むしろ極くまれにしか起らないような、しかるあま り望ましくないと思われるしつけ態度を報告するかる知 れない。

（3）被調查者记記名の責任を執らせるととは，ある
場合にはでたらめ応答を減に゙させるかも知れない。ただ 乙調查結果が親にとつて望ましいと思われる方向に変化 するか, あるいはその逆の方向に変化するかは，一概に 決定することができない。

以上の予想のもとにわれわれは，地方小都市およびそ の近隣農村地域の小中学校児童の親たちに, 教師が生徒 指導のために行う教育調查という条件を定めて, 記名要 因が如何なる作用を及ぼすかを調査した。

\section{III 調 查問題(6)}

われわれのしつけ調查においては, 親の態度の示され る主要な領域を次の八つとした。
(1) 子供の将来
(2) 学 習
(3) 友人
(4) 趣味
(5) 遊 び
(6) 手伝い
(7) 衙生習慣
(8) 礼 䉝

これらの諸領域のそれぞれにおいて，次の四つのしつ けの型があげられる。
1 放任型
口 溺愛型
八 專制型
二 民主型

被調査者は八領域のそれぞれにおいて，子どるに対し て日常如何なるしつけ態度を執つているかを考元, 上述 の四つの型のうちで最もよく忀当するるのに○印をつけ る。

記名の場合の調查問題は次の通りである。なお，無記 名式の調查用紙では，学年・学級・氏名の記入項目が除 かれており，また「1. 気をつけていただくこと」のと ころに,

「ハ.これは学級全体を調べるものでして,一人一人 を調べるものではありません」

という注意書きが附加されている。

印刷上の手遣いから，調查火用いた用枻は記名式・無 記名式とも，遊びの領域の

「ニ。毎日適当な時間だけは危いととをしないかを り，存分遊ばせるようにする。そして遊んできたてと Кついて子どもがいろいる話してくれるよらに気をく ばる。」

の愐目が脱落していた。

\section{調 查 用 紙 (記名式)}

321 高中低 男女一人つ子 長子 末つ子 中間子 これは家庭で，把父さん拇さんが，扣子さんK対し て, 今迄どんな風にあっかつていらつしやつたかを睭い るものです。お子さんの指導上の参考にしたいと思いま 
すからありのまま揊き下さい。くれぐれるありのま まのととを打示し下さい。

1 気をつけていただくこと

1 いっも家でじつさいK，子供さんK対して，とつ て来た態度を書いて下さい。実はころしたいのだと いら見は書加ない上らに。

口この粈を持つて来た子供に対しての慜度を書いて 下さい。他の兄弟姉姝のことではありません。

2 費を方について

1 書いていただくのは埌活扎よ゙阔通 $1-8$ ととついてです。そのーつKついて四つづつの項目 (イロハ か)がありす。その中で一番よくあては まると思われるるのК○をつけて下さい。

口るし四つの項目のらち, 唯一つだけでなぐ, 二つ 以上てあてはまる時は,その数だけ○をつけて下さ w。

へるしあてはまるるのがなければ,その他( ) のところК曹いて下さい。

生活 つぎの四つの中のどれイあてはまるか見つけて イロハニの字の上K○をつけて下さい。

1 必要な学用品は，らくК買えます。

口必要な学用品は, どらにか買えます。

へ必要な学用品は，非常に無理をして買つてやりま す。

二必要な学用品でさえ，買つてやれません。

問夏 イロムニの宇の上Кのをらつて下さい。

1 子供の将来にっいては

1 子供が思らよろК進むがよいと考えてあまりての ことKかまつてやらなかった。

口親の近くКいるよろな仕事で，あまり危くない莀 КつくよらК話しあつて来た。

へ 親の需をつがせるか, 又は摬の望んでいる仕事に つくよろК耳いをかせて来た。

二 子供の能力に合い，子供の好をな仕事によく考元 させて進ませるよらに，つとめて来た。

その他 C

2 学習については

1 子供が宿題について, いろいるきいても，あまり 面倒を見なかった。

口摍題はーしよに上く見て教えてやり，子供の出来 ないとをは，手伝つてやつた。

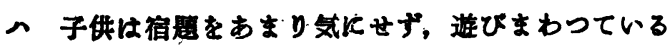
ので，毎日きびしく昔って必ずやらせるよろKして をた。

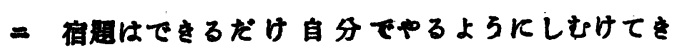

た。いつも子供の勉強に心をくばって，ほめたり， はげましたりしてきた。

その他 C

3 遊び友だちとついては

1 子供ゆ遊び女だちとついては，何す考えていな い。子供のすをなよらにさせでた。

口梚の方でよい友だちを，あれこれ考えて，遊びに 来てくれるよらK，氛をくばつてその友だちと遊ば せるよろにしてをた。

へわるい家庭の子供とは遊济せない。家とつり合つ た家庭の子と，遊壮せるよらにしてきた。

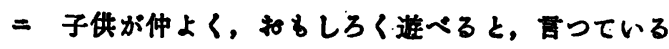
友だちは，どんな性需の子供かそれとなく晭へるよ ラK，気をくばつてきた。

その他 $C$

4 子供の趣味については

1 子供が自分のすきなことをやり出したら，すきな よらにさせてきた。

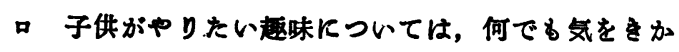
せてやれるよらК，ととのえてやってきた。

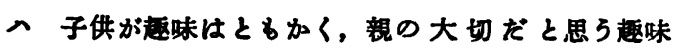
を、どこまでもやらせるよらにしてきた。

二子供か板味をらつたえたら，上く相談して考えて ヤりその上でほしい物はととのえてやつた。

その他 C

5 遊びてっいて

1何をして遊んできても，何も曹わないよらとして \&。

口年るいく危くない所で遊ばせ, 又子供がほしがる 遊び道具は，たいてい買つてやるよらにしてきた。

へ遊びはきりがないので少し遊ばせたら後は家で遊

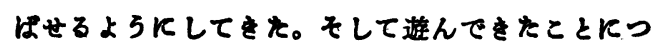
いて，子供がいるいる話してくれるよろK，気をく ばつてをた。

こ毎日適当な時间だりは危いことをしないがりり， 存分遊济せるよらにする。そして遊んできたことに ついて子供がいるいる話してくれるよらに気をくば 3.

その他 $C$

6 手伝については

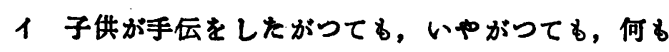
云わずにそのままにしてきた。

口 子供が手伝をするのはかかいそらだから，余り家 の仕事はさせない。手伝をするより好きな事をさせ $\tau$ て民。 
八子供が少しくらい括手伝をいやがつても，必ずや らせるよらにしてきた。

二 家の仕事は家中みんなが話し合つて, 5 けちを わけてやることにしてきた。

その他 (

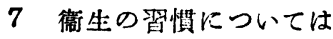

1 食事の時子供が手を洗わなくても，何も言つたこ とはなかつた。

口 食事の時子供㐿を洗うことをいやがれば，手伝 つてやつてでも，せいけつをたもつょらにしてきた。

八子供が手を洗わずに食事をしようとする時は，叱 つてでも毎日きれいに洗わせてきた。

二 子供が手を洗わずに食事をしよ5とする時は，笝 生のことを子供になつとく出来るように話してや り，家の者も子供と同じように契行するようにして 来た。

その他 (

8 揢さんへの礼㵶については

1 揢さんへのあいさつについては，あまり教えな かつた。

口 扣客さんへのあいさつは，そんなKやかましく言 わずに、いつも親がいつしよになつてするよ5にし てきた。

へた客さんへはきちんとあいさつするように，きび しく产つて実行させてきた。

こお客さんへのあいさつは, 子供とよく話し合つ て，子供が自分からなつをくしてするよ5にしむけ てきた。

その他 C

まとめ

1 あなたの家庭で，子供のしつけに一番心をくだいて いるのはつぎの中のどなたですか，○でかこんで下さ いいくつつけてむよろしい。

祖父祖母 父母 兄姑その他

2 この調查の答を書いた人，及び意見を出した方はつ ぎののどなたですか，○でかこんで下さい。

父母 その他( )

\section{IV 研究方法}

\section{（1）調査の方法}

調查用紙は記名式および無記名式の二種類を用いる。 調查はいずれのばあいも，教師が実際教育の必要から行 なうものとして，児童・生徒の親たちに記入してもら う。調查は一力月の期間を隔てて, 第 1 回目調查と第 2 回目調查と合計 2 回行なう。調查計画は第 1 表のとおり
である。

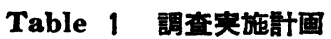

\begin{tabular}{|c|c|c|c|c|}
\hline 学校 & \multicolumn{2}{|c|}{ 小 } & \multicolumn{2}{|c|}{ 校 } \\
\hline 調查順序 & A 校 & B 校 & C 校. & D 校 \\
\hline 第 1 回 & 記名 & 記名 & (每記名) & 無記名 \\
\hline 第 2 回 & 無記名 & 記名 & (記 & 無記名 \\
\hline 学 & \multicolumn{2}{|c|}{ 中 } & 校 & \\
\hline 調查順序 & a 校 & b 校 & c 校 & d 校 \\
\hline 第 1 回 & 記名 & (記 & 無記名 & 無記名 \\
\hline 第 2 回 & 無記名 & (記名) & 記名 & 無記名 \\
\hline
\end{tabular}

\section{（2）被調童者}

つぎの学校の児童・生徒の両親その他。

A校 群馬県山田郡福田村小学校

B校 群馬県山田群相生村小学校

C校 郵送事故のため，資料が得られなかつた。

D校 群馬県山田群毛里田小学校

a 校 群馬県宝泉村宝泉中学校

b 校 郵送事故のため，資料が得られなかつた。

c 校 群馬県佐賀群赤堀中学校

d 校 群馬県佐波郡境町境中学校

尌 6 校 被調查人員 273 人

この被調查校および被調查クラスは，地方小都市およ び串村という钼点から便宜的に選択したのであるから， 厳密な意味における無作為標本選択の理論に基ずいたも のではない。したがつて，推計学的検定をこの調査結果 に適用することは理論的に不可能であるが，この研究に おいてはもしもこれが無作為標本抽出とみなすことがで きるとすればという仮定のもとに，検定を施してある。

\section{(3) 酢查の時期}

1953年 2 月から 3 月までの間に調查を行なつた。

\section{文 調查結果およびその考案}

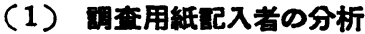

2 回の調查用紙を同一人が記入したばあいが大部分で あるけれども，なお二割程度は第 1 回目調查の記入と第 回 2 目調查の記入とは異る人が記入しているととが判明 した。(第 2 表去照)

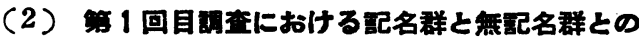 応管分布の比晈}

第2 表から分るように，第1回目調查における記名群 の人数は $(91+54)$ 名 すなわち 145 名であり，無記名群 
Table 2 钎入者の分析

\begin{tabular}{|c|c|c|c|c|c|c|c|c|c|}
\hline $\begin{array}{l}\text { 調 查 の } \\
\text { 順 }\end{array}$ & \multicolumn{3}{|c|}{ 記 $\rightarrow$ 無記 } & \multicolumn{2}{|c|}{ 記 $\rightarrow$ 記無 $\rightarrow$ 記 } & \multicolumn{3}{|c|}{ 無記 $\rightarrow$ 無記 } & 計 \\
\hline 記入者 & $\mathbf{A}$ & a & 計 & B & C & $\mathbf{D}$ & d & 計 & \\
\hline 同一人 & 37 & 27 & 64 & 39 & 43 & 34 & 34 & 68 & 214 \\
\hline 異る人 & 13 & 14 & 27 & 15 & 0 & 7 & 10 & 17 & 69 \\
\hline 尌 & 50 & 41 & 91 & 54 & 43 & 41 & 44 & 85 & 273 \\
\hline
\end{tabular}

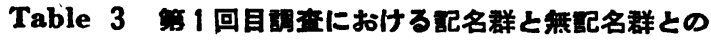
底箁分布の比較

\begin{tabular}{|c|c|c|c|c|c|}
\hline 領域 & 型 & $\begin{array}{c}\text { 記名群 } \\
145 人\end{array}$ & $\left|\begin{array}{c}\text { 無記名群 } \\
128 \text { 人 }\end{array}\right|$ & 分布の検定 & $\begin{array}{l}\text { 有 } \\
\text { 意 } \\
\text { 性 }\end{array}$ \\
\hline $\begin{array}{l}\text { 生 } \\
\text { 活 }\end{array}$ & $\begin{array}{l}1 \text {.学用品はらくにかう } \\
\text { 号うにか } \\
\text { 八 非常に無理する } \\
=\text { 買えない } \\
\end{array}$ & $\begin{array}{c}17.9 \% \\
69.7 \\
11.7 \\
0.7 \\
\end{array}$ & \begin{tabular}{c|}
$18.9 \%$ \\
57.6 \\
18.2 \\
5.3 \\
\end{tabular} & $\begin{array}{l}x^{2}=6.3727 \\
\mathrm{df}=2 \\
.02<P<.05\end{array}$ & * \\
\hline $\begin{array}{c}1 \\
\text { 将 } \\
\text { 来 }\end{array}$ & 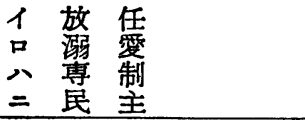 & $\begin{array}{l}23.6 \\
14.2 \\
11.0 \\
51.2\end{array}$ & $\begin{array}{r}23.8 \\
5.6 \\
22.2 \\
48.4 \\
\end{array}$ & $\begin{array}{l}\chi^{2}=7.087 \\
\mathrm{df}=3 \\
.05<P<.10\end{array}$ & \\
\hline $\begin{array}{l}2 \\
\text { 算 }\end{array}$ & $\begin{array}{l}1 \\
\text { 品 } \\
\text { N } \\
=\end{array}$ & $\begin{array}{r}19.6 \\
21.6 \\
8.5 \\
60.3\end{array}$ & $\begin{array}{r}22.3 \\
22.3 \\
6.5 \\
48.9\end{array}$ & $\begin{array}{l}\chi^{2}=.6414 \\
\mathrm{df}=3 \\
.80<\mathrm{P}<.90\end{array}$ & \\
\hline $\begin{array}{l}3 \\
\text { 友 } \\
\text { 人 }\end{array}$ & $\begin{array}{l}1 \\
\text { 口 } \\
\text { 至 } \\
=\end{array}$ & $\begin{array}{l}41.8 \\
12.4 \\
13.0 \\
32.7\end{array}$ & $\begin{array}{l}44.4 \\
10.6 \\
14.8 \\
30.3\end{array}$ & $\begin{array}{l}x^{2}=.5607 \\
\mathrm{df}=3 \\
.90<P<.95\end{array}$ & \\
\hline $\begin{array}{l}4 \\
\text { 趣 } \\
\text { 味 }\end{array}$ & $\begin{array}{l}1 \\
\square \\
N \\
= \\
\end{array}$ & $\begin{array}{r}41.0 \\
12.2 \\
7.1 \\
39.7 \\
\end{array}$ & $\begin{array}{r}45.3 \\
7.4 \\
5.4 \\
41.8 \\
\end{array}$ & $\begin{array}{l}\chi^{2}=2.4012 \\
\mathrm{df}=3 \\
.30<\mathrm{P}<.60\end{array}$ & \\
\hline $\begin{array}{c}\mathbf{5} \\
\text { 遊 } \\
\text { び }\end{array}$ & $\begin{array}{l}1 \\
\square \\
\therefore \\
= \\
\end{array}$ & $\begin{array}{r}20.2 \\
38.4 \\
41.3 \\
-\end{array}$ & $\begin{array}{r}26.2 \\
32.5 \\
41.3 \\
-\end{array}$ & $\begin{array}{l}\chi^{2}=1.6032 \\
\mathrm{df}=2 \\
.30<\mathrm{P}<.60\end{array}$ & \\
\hline $\begin{array}{l}6 \\
\text { 手 } \\
\text { 伝 }\end{array}$ & $\begin{array}{l}1 \\
\square \\
N \\
= \\
\end{array}$ & $\begin{array}{r}8.7 \\
6.7 \\
46.3 \\
40.3 \\
\end{array}$ & $\begin{array}{r}1.4 \\
5.0 \\
40.3 \\
53.2 \\
\end{array}$ & $\begin{array}{l}\chi^{2}=8.0480 \\
\mathrm{df}=3 \\
.02<\mathrm{P}<.05\end{array}$ & * \\
\hline $\begin{array}{c}7 \\
\text { 衛翼 } \\
\text { 生疅 }\end{array}$ & $\begin{array}{l}1 \\
\square \\
N \\
= \\
\end{array}$ & $\begin{array}{l}20.9 \\
23.0 \\
29.7 \\
26.4 \\
\end{array}$ & $\begin{array}{l}20.8 \\
10.4 \\
33.6 \\
35.2 \\
\end{array}$ & $\begin{array}{l}\chi^{2}=8.2181 \\
\text { df }=3 \\
.02<P<.05\end{array}$ & $*$ \\
\hline $\begin{array}{l}8 \\
\text { 礼 } \\
\text { 檥 }\end{array}$ & $\begin{array}{l}1 \\
D \\
N \\
= \\
\end{array}$ & $\begin{array}{r}31.4 \\
35.0 \\
9.3 \\
24.3 \\
\end{array}$ & $\begin{array}{l}28.8 \\
21.6 \\
16.8 \\
32.8 \\
\end{array}$ & $\begin{array}{l}\chi^{2}=8.8682 \\
\mathrm{df}=3 \\
.02<P<.05\end{array}$ & * \\
\hline $\begin{array}{c}1 \sim 8 \\
\text { 拿 } \\
\text { 計 }\end{array}$ & $\begin{array}{l}1 \\
0 \\
\therefore \\
=\end{array}$ & $\begin{array}{l}26.1 \\
20.2 \\
20.4 \\
33.2 \\
\end{array}$ & $\begin{array}{l}26.7 \\
14.1 \\
22.0 \\
37.1 \\
\end{array}$ & $\begin{array}{l}\chi^{2}=14.1211 \\
\text { df }=3 \\
P<.01\end{array}$ & * \\
\hline $\begin{array}{l}1.2 .3 \\
4.6 .7 \\
8 \\
\text { 合 } \\
\text { 訊 }\end{array}$ & $\begin{array}{l}1 \\
0 \\
\therefore \\
=\end{array}$ & $\begin{array}{l}26.9 \\
17.7 \\
17.7 \\
37.7\end{array}$ & $\begin{array}{l}26.8 \\
11.7 \\
19.5 \\
42.1\end{array}$ & $\begin{array}{l}\chi^{2}=15.419 \\
\text { df }=3 \\
P<.01\end{array}$ & * \\
\hline
\end{tabular}

の人数は $(43+85)$ 名 すなわち 128 名である。これらの被調查者につい て，記名のばあいの応答と無記名の ばあいの応答との間にいかなる差異 があるかを検討すると，第 3 表のと おりの結果が得られた。

これによると，記名群と無記名群 との間には, 将来・学習・友人・趣 味・遊びの 5 領域に関して応答分布 に有意な差異が見られない。しかし ながら，手伝い・徫生習慣・礼儀の 3 領域に関しては, 両群の応答分布 に 5 パーセントの危険率で有意な差 異が見られた。8領域中 3 領域だけ が 5 パーセントの危険率で有意な差 異があり，他の 5 領域に関しては有 意差がないということは，Wilkinson の表 (7)に従えば，全体として 両群には有意な差異がないととにな る。したがつて，このような観点か らこの調査問題におよほすす記名・無 記名の要因を検討するならば，この 要因は調查結果にほとんど影響を及 ぼさないといえる。

しかしながら，8領域の分布の合 計および遊びの領域を除いた7 領域 の分布の合計について, 記名群之無 記名群とを比較すると，いずれむ有 意な差異が見られることおおび手 伝・衙生習慣・礼儀の 3 領域はそれ ぞれ両群に有意な差異があることが 問題となる。

この二つの問題に関して共通な傾 向は，無記名調査のばあいには，記 名調查のばあいよりも民主型が増加 していることである。このことに関 しては, つきに評価值の観点から検 討する。

\section{（3）第 1 回目娚查になける記 名群と無記名群との応答 の評価值による比故}

われわれはこの研究と汹別につぎ のような研究(8) を行なつた。すな わ方８領域のそれぞれのしつけの 型に対して, 群騠太田市近隣の児 
童の親たちに，教育的に考えてどの程度望ましいかをら 段階尺度法によつて評価させた。その結果，第 4 表のよ うな評価值が得られた。

Table 4 しつけの囬に対する親の平均枰価值

\begin{tabular}{|c|c|c|c|c|c|}
\hline 領 域 & 型 & 評価值 & 領 域 & 型 & 評価值 \\
\hline \multirow[t]{4}{*}{ 1. 将来 } & 1. 放任 & -.49 & \multirow[t]{4}{*}{ 5. 遊び } & 1. 放任 & -1.07 \\
\hline & 口. 溺愛 & .60 & & 口. 弱带 & .36 \\
\hline & 八. 専制 & .07 & & 八. 專制 & 1.01 \\
\hline & =. 民主 & 1.66 & & =. 民主 & 1.29 \\
\hline \multirow[t]{4}{*}{ 2. 学習 } & 1. 放任 & -.90 & \multirow[t]{4}{*}{ 6. 手伝 } & 1. 放任 & -1.09 \\
\hline & 口. 溺愛 & .75 & & ㅁ. 㸤 & -1.03 \\
\hline & 八. 専制 & -.85 & & 八. 専制 & .86 \\
\hline & 二，民主 & 1.62 & & $=$. 民主 & 1.61 \\
\hline \multirow[t]{4}{*}{ 3. 友人 } & 1. 放任 & -.64 & \multirow{4}{*}{$\begin{array}{l}\text { 7. 徨生 } \\
\text { 㿢慣 }\end{array}$} & 1. 放任 & -1.33 \\
\hline & 口. 溺愛 & .36 & & 口. 溺愛 & 1.05 \\
\hline & 八. 専制 & .08 & & 八. 専制 & 1.11 \\
\hline & =，民主 & 1.22 & & 二，民主 & 1.67 \\
\hline \multirow[t]{4}{*}{ 4. 趣味 } & イ. 放任 & .61 & \multirow[t]{4}{*}{ 8. 礼儀 } & 1. 放任 & -.90 \\
\hline & 口. 溺愛 & .42 & & 口. 溺愛 & .60 \\
\hline & 八. 専制 & -.22 & & 八. 専制 & .38 \\
\hline & $\begin{array}{l}\text { 二，民主 } \\
N=193\end{array}$ & 1.47 & & =，民主 & $1 \cdot 43$ \\
\hline
\end{tabular}

この評価値を用いて，第 1 回目調查における記名群の 応答と無記名群の応答との平均評価値を算出すると，第 5 表のとおりとなる。第 5 表によると，将来・学習・友 人・遊びの 4 領域は記名群の方が無記名群よりも高い平 均評価値を示しているが、これは統計的に有意なもので 汭い。ところが, 手伝, 语生習慣, 礼儀, および全領 域の平均, 遊びを除く七領域の平均に関しては, 平均評 価值は無記名群の方が記名群よりも有意的に高い。けれ ぞもこれらの有意な差異も，その值は 0.3 以下で心理 学的には大きないみを持たないから，記名一無記名要因 は調查結果にほとんど差異をもたらさないと結論でき る。

\section{（4）第 1 回目調查と第 2 回目調查との間に生ずる 変動についての考察}

1 カ月の期間を掞いて, 調查を 2 回実施したが， 2 回 とも同じ人が記入した資料についてのみ，その間に生じ た変動を検討した。(第 2 表至照) 第 1 回目の記入結果
Table 5 第 1 回目調坴における記名群の平㘬 评価健と無祀名群の平均評価值

\begin{tabular}{|c|c|c|c|}
\hline 域 & 記名群 & 無記名群 & 有意性 \\
\hline 1. 将 & .826 & $>.736$ & \\
\hline 2. 学 & .873 & $>.814$ & \\
\hline 3. 友 & .186 & $>.135$ & \\
\hline 4. 趣 & .870 & $<.910$ & \\
\hline 5. 遊 & .565 & $>.204$ & \\
\hline 6. 手 & .865 & $<1.136$ & * \\
\hline 7. 副生 習慣 & .733 & $<.793$ & $*$ \\
\hline 8. 礼 & .275 & $<.382$ & $*$ \\
\hline $1 \sim 8$ 平 均 & .661 & $<.704$ & ** \\
\hline $\begin{array}{lll}\text { 1. } & 2.3 . & 4.6 . \\
7.8 . & \text { 平 均 }\end{array}$ & .649 & $<.661$ & ** \\
\hline
\end{tabular}

有意性の検定は，第 3 表の $x^{2}$ 検定による。

と第 2 回目の記入結果とを，各領域ごとに第 4 表の平均 評価值に照して検討し，第 1 回目より第 2 回目の方がよ り高い評定値を持つ項目に記入されているときには「良」 として，2回とも同し項目に○印がつけられているとき には「同一」とし，項目が異なつていてもその間に評定 価の差が 0.5 より小さいときには「ほほ同」とし，2回 目に記入されている項目が1回目に記入されている項目 よりも低い評定価を持的項目に○印がつけられていると きには「悪」として整理した。この四つの策閧する 疬答分布について統計的に検討したのが第の表である。

第6 表を見ると（記名 $\rightarrow$ 無記名）群と（無記名 $\rightarrow$ 無記 名) 群との間には, 2 回の調査の变動に関してはほとん ど美異がないととが分る。また，(記名十無記名）群， （記名 $\rightarrow$ 記名）群，(無記名 $\rightarrow$ 記名) 群，(無記名 $\rightarrow$ 無 記名) 群の 4 群の間に，変動の差異が見られるのは 8 領 域中将来の 1 領域だけで，Wilkinson の表を適用すれ ば明らかに 8 領域に関して 4 群の間に差異がないことに なる。ただ注意しなければならないととは８領域を合 計すると 4 群の間に有意な差異があるととである。との 点に関しては今後なお検討しなければならない。

以上の検討から，記名一無記名要因は，2回の調查間 において生ずる変動にほとんど影響を及汇さないと結論 できる。

\section{VI 要䄪および結論}

しつけ調查において，記名式と無記名式といずれがょ いかを決定するためにまず被調查者の署名が調查結果 
Table 6 第 1 回目調套と第 2 回目調查との間におこる変勳の比較

\begin{tabular}{|c|c|c|c|c|c|c|c|c|c|c|c|}
\hline & & & & & & \multirow{2}{*}{\multicolumn{2}{|c|}{ の 検 定 }} \\
\hline & & & & & & & & & & & \\
\hline & & 記 $\rightarrow$ & 無記 & 記 $\rightarrow$ & 記 & 無記 & $\rightarrow$ 記 & 無記一 & ＞無記 & $\begin{array}{l}\text { 記 } \rightarrow \text { 無記之 } \\
\text { 無記 } \rightarrow \text { 無記 }\end{array}$ & $\begin{array}{l}\text { 記 } \rightarrow \text { 無記 記 } \rightarrow \text { 記 } \\
\text { 無記 } \rightarrow \text { 記 } \\
\text { 無記 } \rightarrow \text { 無記 }\end{array}$ \\
\hline 活 & 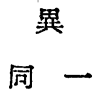 & $\begin{array}{l}(10) \\
(56)\end{array}$ & $\begin{array}{l}15.2 \% \\
84.8\end{array}$ & $\begin{array}{l}(5) \\
(36)\end{array}$ & $\begin{array}{l}12.2 \% \\
88\end{array}$ & $\begin{array}{l}(14) \\
(29)\end{array}$ & $\begin{array}{l}32.4 \% \\
67.6\end{array}$ & $\begin{array}{l}(11) \\
(53)\end{array}$ & $\begin{array}{l}17.2 \% \\
82.8\end{array}$ & $\begin{array}{l}x^{2}=.9944 \\
\mathrm{df}=1 \\
.30<\mathrm{P}<.50\end{array}$ & $\begin{array}{l}x^{2}=7.1510 \\
\text { df }=3 \\
.05<P<.10\end{array}$ \\
\hline $\begin{array}{c}1 \\
\text { 将 } \\
\text { 来 }\end{array}$ & 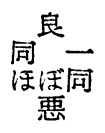 & $\begin{array}{l}(10) \\
(34) \\
(0) \\
(16)\end{array}$ & $\begin{array}{r}16.7 \\
56.7 \\
0 \\
26.7\end{array}$ & $\begin{array}{l}(6) \\
(29) \\
(5) \\
(0)\end{array}$ & $\begin{array}{l}15 \\
72.5 \\
12.5 \\
0\end{array}$ & $\begin{array}{l}(13) \\
(22) \\
(0) \\
(3)\end{array}$ & $\begin{array}{r}34.2 \\
57.9 \\
0 \\
7.9\end{array}$ & $\begin{array}{l}(9) \\
(45) \\
(0) \\
9\end{array}$ & $\begin{array}{r}14.2 \\
71.4 \\
0 \\
14.2\end{array}$ & $\begin{array}{l}x^{2}=.3469 \\
\mathrm{df}=2 \\
.80<\mathrm{P}<.90\end{array}$ & $\begin{array}{l}x^{2}=21.4366 \\
\mathrm{df}=6 \\
\mathrm{P}<.01\end{array}$ \\
\hline $\begin{array}{l}2 \\
\text { 学 } \\
\text { 習 }\end{array}$ & $\begin{array}{c}\text { 同 } \\
\text { ほ良 } \\
\text { 悪 } \\
\text { 闸 }\end{array}$ & $\begin{array}{l}(13) \\
(42) \\
(2) \\
(10)\end{array}$ & $\begin{array}{r}19.4 \\
62.7 \\
2.9 \\
14.9\end{array}$ & $\begin{array}{l}(5) \\
(37) \\
(2) \\
(6)\end{array}$ & $\begin{array}{r}10 \\
74 \\
4 \\
12\end{array}$ & $\begin{array}{l}(7) \\
(24) \\
(11)\end{array}$ & $\begin{array}{r}16.7 \\
67.2 \\
0 \\
26.2\end{array}$ & $\begin{array}{l}(11) \\
(44) \\
(2) \\
(11)\end{array}$ & $\begin{array}{r}16.1 \\
64.8 \\
2.9 \\
16.1\end{array}$ & $\begin{array}{l}x^{2}=.3003 \\
\mathrm{df}=2 \\
.80<P<.90\end{array}$ & $\begin{array}{l}x^{2}=6.19256 \\
\mathrm{df}=6 \\
.30<\mathrm{P}<.50\end{array}$ \\
\hline $\begin{array}{c}3 \\
\text { 遊友 } \\
\text { び達 }\end{array}$ & 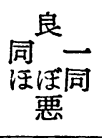 & $\begin{array}{l}(9) \\
(33) \\
(5) \\
(16)\end{array}$ & $\begin{array}{r}13.2 \\
48.5 \\
1.7 \\
23.2\end{array}$ & 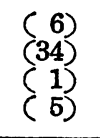 & $\begin{array}{l}13.0 \\
74 \\
2.2 \\
18.9\end{array}$ & $\begin{array}{l}(8) \\
(28) \\
(1) \\
(10)\end{array}$ & $\begin{array}{r}17.1 \\
59.6 \\
2.1 \\
21.2\end{array}$ & $\begin{array}{l}(14) \\
(44) \\
(1) \\
(7)\end{array}$ & $\begin{array}{r}21.2 \\
66.7 \\
1.5 \\
10.6\end{array}$ & $\begin{array}{l}x^{2}=5.1412 \\
\mathrm{df}=2 \\
.05<\mathrm{P}<.10\end{array}$ & $\begin{array}{l}x^{2}=8.270166 \\
\mathrm{df}=6 \\
.20<\mathrm{P}<.30\end{array}$ \\
\hline $\begin{array}{c}4 \\
\text { 趣 } \\
\text { 昧 }\end{array}$ & $\begin{array}{l}\text { 同 } \\
\text { 良添同 } \\
\text { 悪 } \\
\text { 覀 }\end{array}$ & $\begin{array}{l}(14) \\
(39) \\
(1) \\
(9)\end{array}$ & $\begin{array}{r}22.2 \\
61.9 \\
1.5 \\
14.2\end{array}$ & $\begin{array}{l}(5) \\
(36) \\
(1) \\
(7)\end{array}$ & $\begin{array}{r}13 \\
73.5 \\
2.2 \\
14.3\end{array}$ & $\begin{array}{l}(5) \\
(31) \\
(1) \\
(5)\end{array}$ & $\begin{array}{r}11.9 \\
73.9 \\
2.4 \\
11.9\end{array}$ & $\begin{array}{l}(7) \\
(48) \\
(3) \\
(13)\end{array}$ & $\begin{array}{r}9.8 \\
67.7 \\
4.2 \\
18.3\end{array}$ & $\begin{array}{l}x^{2}=4.5224 \\
\mathrm{df}=2 \\
.10<\mathrm{P}<.20\end{array}$ & $\begin{array}{l}x^{2}=11.85705 \\
\mathrm{df}=6 \\
.05<\mathrm{P}<.10\end{array}$ \\
\hline $\begin{array}{l}5 \\
\text { 遊 } \\
\text { び }\end{array}$ & $\begin{array}{l}\text { 同 } \\
\text { ほ良悪 } \\
\text { 同 }\end{array}$ & $\begin{array}{l}(8) \\
(36) \\
(0) \\
(16)\end{array}$ & $\begin{array}{r}13.3 \\
60 \\
0 \\
2.7\end{array}$ & $\begin{array}{l}(3) \\
(29) \\
(0) \\
7)\end{array}$ & $\begin{array}{r}7.7 \\
74.4 \\
0 \\
17.9\end{array}$ & $\begin{array}{l}(7) \\
(23) \\
(0) \\
(8)\end{array}$ & $\begin{array}{r}18.4 \\
60.5 \\
0 \\
21.2\end{array}$ & $\begin{array}{l}(11) \\
(36) \\
(0) \\
(10)\end{array}$ & $\begin{array}{r}19.3 \\
63.2 \\
0 \\
17.5\end{array}$ & $\begin{array}{l}x^{2}=1.7828 \\
\mathrm{df}=2 \\
.30<\mathrm{P}<.50\end{array}$ & $\begin{array}{l}x^{2}=8.841356 \\
\mathrm{df}=6 \\
.10<\mathrm{P}<.20\end{array}$ \\
\hline $\begin{array}{l}6 \\
\text { 手 } \\
\text { 伝 }\end{array}$ & $\begin{array}{c}\text { 同 } \\
\text { ほ良 } \\
\text { 悪 } \\
\text { 票 }\end{array}$ & $\begin{array}{l}(9) \\
(39) \\
(0) \\
(16)\end{array}$ & $\begin{array}{r}14.5 \\
60.9 \\
0 \\
25.0\end{array}$ & $\begin{array}{l}(3) \\
(28) \\
(1) \\
(5)\end{array}$ & $\begin{array}{r}8.1 \\
75.6 \\
2.7 \\
13.5\end{array}$ & $\begin{array}{l}(4) \\
(34) \\
(0) \\
(6)\end{array}$ & $\begin{array}{r}9.1 \\
77.2 \\
0 \\
13.6\end{array}$ & $\begin{array}{l}(8) \\
(49) \\
(1) \\
(9)\end{array}$ & $\begin{array}{r}11.9 \\
73.1 \\
1.5 \\
13.4\end{array}$ & $\begin{array}{l}x^{2}=3.3069 \\
\mathrm{df}=2 \\
.10<\mathrm{P}<.20\end{array}$ & $\begin{array}{l}x^{2}=6.09394 \\
\mathrm{df}=6 \\
.30<\mathrm{P}<.50\end{array}$ \\
\hline $\begin{array}{l}7 \\
\text { 徨 } \\
\text { 生 }\end{array}$ & $\begin{array}{c}\text { 同 } \\
\text { ほぼ同 } \\
\text { 悪 }\end{array}$ & $\begin{array}{l}(9) \\
(34) \\
(5) \\
(8)\end{array}$ & $\begin{array}{r}16.0 \\
60.7 \\
8.9 \\
14.2\end{array}$ & $\begin{array}{l}(4) \\
(26) \\
(6) \\
(6)\end{array}$ & $\begin{array}{r}9.5 \\
61.9 \\
14.3 \\
14.3\end{array}$ & $\begin{array}{l}(6) \\
(21) \\
(2) \\
(5)\end{array}$ & $\begin{array}{r}17.6 \\
61.8 \\
5.8 \\
14.7\end{array}$ & $\begin{array}{l}(10) \\
(37) \\
(6) \\
(7)\end{array}$ & $\begin{array}{l}16.7 \\
61.7 \\
10.0 \\
11.2\end{array}$ & $\begin{array}{l}x^{2}=0.1770 \\
\mathrm{df}=2 \\
.98<P<.99\end{array}$ & $\begin{array}{l}x^{2}=1.519488 \\
\mathrm{df}=6 \\
.95<P<.98\end{array}$ \\
\hline $\begin{array}{l}8 \\
\text { 礼 } \\
\text { 義 }\end{array}$ & $\begin{array}{l}\text { 同 } \\
\text { 良 } \\
\text { 悪 }\end{array}$ & $\begin{array}{l}(11) \\
(33) \\
(0) \\
(13)\end{array}$ & $\begin{array}{r}19.3 \\
57.8 \\
0 \\
22.8\end{array}$ & $\begin{array}{l}(7) \\
(25) \\
(3) \\
(5)\end{array}$ & $\begin{array}{r}17.3 \\
62.3 \\
7.5 \\
12.5\end{array}$ & $\begin{array}{l}(7) \\
(25) \\
(1) \\
(7)\end{array}$ & $\begin{array}{r}17.5 \\
62.5 \\
2.5 \\
17.5\end{array}$ & $\begin{array}{l}(13) \\
(35) \\
(3) \\
(16)\end{array}$ & $\begin{array}{r}19.7 \\
63.1 \\
4.5 \\
22.6\end{array}$ & $\begin{array}{l}x^{2}=0.0032172 \\
\mathrm{df}=2 \\
.98<\mathrm{P}<.99\end{array}$ & $\begin{array}{l}x^{2}=2.8014 \\
\mathrm{df}=6 \\
.80<P<.90\end{array}$ \\
\hline $\begin{array}{l}1 \sim 8 \\
\text { 鿖 } \\
\text { 訪 }\end{array}$ & 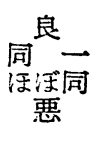 & $\begin{array}{r}(83) \\
(290) \\
(13) \\
(104)\end{array}$ & $\begin{array}{r}16.9 \\
59.2 \\
2.7 \\
21.2\end{array}$ & $\begin{array}{r}(39) \\
(244) \\
(19) \\
(41)\end{array}$ & $\begin{array}{r}11.4 \\
71.1 \\
5.5 \\
12.0\end{array}$ & $\begin{array}{r}(57) \\
(208) \\
(5) \\
(55)\end{array}$ & $\begin{array}{r}17.5 \\
64.0 \\
1.5 \\
17.0\end{array}$ & $\begin{array}{r}(83) \\
(338) \\
(16) \\
(81)\end{array}$ & $\begin{array}{r}16.0 \\
65.3 \\
3.1 \\
15.6\end{array}$ & $\begin{array}{l}x^{2}=6.0647 \\
\mathrm{df}=3 \\
.10<P<.20\end{array}$ & $\begin{array}{l}x^{2}=30.160736 \\
d f=9 \\
P<.01\end{array}$ \\
\hline
\end{tabular}

括弧内は実数。

にいかなる差異をもたらすかを検討した。調查は，教師 が行なう教育調查という実践的な条件下において, 群馬 県の一小都市およびその周辺の農村地带の小中学校児童 の親たちについて行なつた。その結果, 第 1 回目調查に 颃いても，また第 1 回目調查と第 2 回目調查（間隔は 1 カ月) との間汇起る变動汅打いても, 記名要因はほとん ど有意味な作用をしていないことが明らかになつた。し 於がつて，われわれが今後しつけの文化型を研究してゅ
く際には，実際的な便利から記名調查用紙を用いること に決定した。(いうをでもなくこの結論は, 限られた調 查対象についての子適用されるべきものである

附記

この調查研究の実施にあたつて多大の御協力を与えて くださつた, 福田村小学校教官松島昭吉氏, 相生小学校 教官能塚誠一氏，毛里田小学校教官青木嗣夫氏，宝泉中 学校教官境茂氏, 赤堀中学校教官小林登志子氏, 境中学 
校教官手島敬吉氏に深い謝意を表します。

\section{文䰚}

(1) Koos, Leonard V. ; The Questionnaire in Education. New York : MacMillan Co. 1928. p. 106-109.

(in "The Waiver of Signature in Personal Reports by Olson, Willard C. ; J of appl. Psychol., 1936 20. p. 442-450)

(2) Maller, Julius B. ; The Effect of Signing Ones' name, School and Society, 1930. 31. p. 882-884.

(in Olson's Monograph, op. cit)

(3) Olson, Willard C. : Tha Waiver of Signature in Personal Reports J. of. appl. Psy- chol. , 1936, 20, p. 442-460.

(4) Fischer, R.P. ; Signed versus Unsigned Personal Questionnaires. J. of appl. Psychol. , 1946. 30, p. 220-225 (Abstract)

（5）松井資夫・羽場究; 採用試験時に扣ける自己評 定 応用心理学会第15回大会発表

（6）石黑大義; 溺愛・放任・専制 览童心理第 8 巻 9 号 金子書房

(7) Wilkinson, Bryan; A Statistical Consideration in Psychological Research., Psychol. Bull. , 1951, 48, p. 156-158.

（8）石黑大義・藤原喜悦；しつけ態度の型に対する 親の評価 教育心理第 1 巻第 9 号 日本交化科学 社 
general, they were not inferior, but quite normal.

They say that prematurely born children are inferior, when they are very young. But we do not necessary hear this, when they enter into teenages. It seems to us they are evaluated by undue C.A. when young, but their true developmental ratio appear soon or later.

(5) This formula, too, has a disadvantage, because two different developmental phases of prenatal and postnatal periods are treated as the same. (This is apparent in the sign of plus.) While the development of prenatal period is chiefly physiological, and potential, we should say, in a psychological aspect, the postnatal one is convergent of physiological growth and environ- mental stimuli. A child whose developmental ratio is higher than 1.25 , and who is born at 8 th month, may be unduly advantageous, because he has greater percentage of periods when he is stimulated by outside experiences, being acceptable of them even at the time of premature birth. Here is a possibility of re-correction.

Though we can say, at any rate, that $t+a$ $(x>0)$ instead of $t$ in the denominater may be better, that this $\alpha$ might be expressed

$$
a=(10-t) \times c \quad(1>c>0)
$$

and that $c$ should be determined experimentally, it is very difficult for us, because our present scales of physiological and psychological measurements are too rough and poor for these purposes.

\title{
SIGNED VERSUS UNSIGNED.QUESTIONNAIRES OF THE PATTERN OF PARENTAL ATTITUDE TOWARD CHILDREN
}

\author{
-A strdy of Questionnaire Method -
}

Nagoya University

Noma Institute of Educational Research Fujiwara, Kietsu

\section{Purpose :}

In our study upon the pattern of parental attitude toward children, we made the questionnaire in which parents were asked of their daily attitude. But in the administration of this questionnaire, the effect of signing one's name upon the result of it should be taken into consideration. If any significant difference between the results of the signed and the unsigned questionnaires could not be noticed, we should be allowed to employ the signed questionnaire in our future study. If not, we should investigate the causes of it and determine which of the two, the signed and the unsigned questionnaires, was more suitable to our study.

This paper mainly dealt with the effect of signature upon the parental reports of their atti- tude toward children.

Method :

In our questionnaire, parents were asked which one of the four patterns (non-iilterferent, overprotected, authoritarian and democratic) agreed with that which were really adopted by them in their attitude toward their children. All the subjects were divided into four groups (signedunsigned, signed-signed, unsigned-signed and unsigned-unsigned) and they were tested twicely by the interim of one month. The research plan can be seen in Table 1.

The number of subjects was 273 and they were selected at our convenience from those who lived near Ota City in Gumma Prefecture. Our research was conducted during February and March of 1953. 


\section{Results :}

Between the resuits of the unsigned and the signed group concerning the initial test, we could find significant difference in only three areas out of eight so that we could not recognize any significant effect of signature upon the result of our questionnaire. In addition to this, we could not also find any significant difference between the variations during the interim of one month among the four groups.
Conclusion :

In our study, we could not find any signiticant effect of signature upon the result of parental reports of their daily attitude toward children. Therefore, we should be allowed to employ the signed questionnaire in our future research. ( $P$ ut we should be careful of the limitation of this conclusion that our results were not based upon the random sampie procedure. )

\title{
A STUDY OF THE CORRELATION BETWEEN PERSONAL CHARACTER AND THE DEGREE OF PHYSICAL MATURATION
}

\author{
By Ohira, Katsuma \\ Kanazawa University.
}

The present paper is a report on the study of the correlation between the degree of physical maturation, determined by the pianimetric method of carpal bones, and personal character which is appraised by using Kraepelin numeral addition test, adjustment test and moral judgment test. The research and experiment were made during the period from May, 1952 to Octoker, 1952. The number of subjects is 102 - from 4 th grade to 6 th grade of e'ementary school children.

The abstract of the result is as follows:

1) the author found that there is correlation coeffic:ent. 311 between the dezree of physical maturation (indicated by growth quotient $=\mathrm{G}$. Q) and the result of Kraepelin numeral addition test (indicated by Standard Score) and the $r$ is significant at 1 percent level.

2) The $r$ between physical maturation degree and the result of adjustment test is .195 and the $r$ is insignificant at the 5 percent level. But there is correlation ratio .423 and the difference between $\gamma$ and $\eta$ is significant at the 5 percent level.
3) The result of moral judgment test indicates $\gamma$. 228 or $\eta$. 505 between the result and the physical maturation degree; then the $r$ and the difference between $\gamma$ and $\eta$ are respectively significant at the 5 percent level.

4) There are deeper correlations between the result of three tests of personal character which were used in this study and the intelligence than the correlation between the test results and bodily maturation degree. Furthermore, the author studied last year that there is the low correlation between the physical maturation degree and intelligence. So if we recognize the common factor of intelligence between personal character and physical maturation degree, and remove the common intelligence factor, there is no corre'ation between personal character and bodily maturation degree. However if we do not consider about the intelligence factor, the author may conclude that there is actually a low but considarable correlation between personal character and physical maturation degree. 